\title{
The Position of Amicus Curiae under the Indonesian Law of Evidence
}

\author{
Fadil Aulia1, Muchlas Rastra Samara Muksin ${ }^{2}$ \\ ${ }^{1}$ Master Of Legal Science, Faculty of Law, Universitas Gadjah Mada, Indonesia \\ ${ }^{2}$ Master Of Legal Science, Faculty of Law, Universitas Diponegoro, Indonesia \\ E-mail: ${ }^{1}$ fadilsyahrin97@gmail.com \\ 2muchlasmuksin02@gmail.com
}

\begin{tabular}{l} 
ARTICLE INFO \\
\hline Keywords: \\
amicus curiae; law of \\
evidence; criminal \\
procedure \\
How to cite: \\
Aulia, F. E Muksin, M. R. \\
S. (2020). The Position of \\
Amicus Curae under the \\
Indonesian Law of \\
Evidence. Jurnal Media \\
Hukum, 27(2), 206-216 \\
Article History: \\
Received: 12-09-2020 \\
Reviewed: 05-11-2020 \\
Revised: 27-11-2020 \\
Accepted: 05-12-2020
\end{tabular}

\begin{abstract}
The use of amicus curiae has been common in Indonesia, especially in criminal courts. Although there is no clear regulation on amicus curiae, in practice, it has been submitted more than 24 times to the courts. Even there are some judges who consider amicus curiae in making their decisions. This paper aims to determine and examine the legal standing and the strength of amicus curiae under the Indonesian law of evidence. This normative legal research relies on the secondary data in the form of legal material. It is found that the opinion of an amicus curiae, which is usually submitted to the court in written form, could be used as a documentary evidence as intended in Article 187 of the Criminal Procedure Code. However, it has no binding force. Therefore, the judges are free whether or not to consider the opinion submitted by the amicus curiae.
\end{abstract}

DOI: 10.18196/jmh.20200152

Copyright (C) 2020 JURNAL MEDIA HUKUM. All rights reserved.

\section{Introduction}

Proving constitutes the most crucial phase within the legal proceeding, especially criminal proceedings. Proving the guilt of the defendant must not be done arbitrarily. For this purpose, the presence of valid evidences is really necessary since it affects the conviction of the defendant. Proving in criminal procedural law aims to obtain legal truth because the absolute truth is difficult to obtain. ${ }^{1}$

Article 184 of the Indonesian Code of Criminal Procedure (KUHAP) suggests five categories of evidence consisting of: (1) witness testimony; (2) expert testimony; (3) documentary evidence; (4) circumstantial evidence; and (5) the accused testimony. Amicus Curiae (literally means Friend of the Court) is a person or group who is not a

\footnotetext{
${ }^{1}$ Muhammad, R. (2007). Contemporary Criminal Procedure Law. Bandung: PT. Citra Aditya Bakti, p. 185.
} 
party to an action, but has a strong interest in the matter and submit a brief in the action with the intent of influencing the court's decision. ${ }^{2}$

In the last few years, the term Amicus Curiae has appeared in the Indonesian Court. There are differences of opinion among legal experts regarding the origin of Amicus Curiae. Many jurists believe that this concept comes from the Roman legal tradition. ${ }^{3}$ In line with civilization's development in the fourteenth century, Amicus Curiae began to be practiced in common law countries. ${ }^{4}$ Indonesia basically does not recognize Amicus Curiae's existence within its judicial system, especially the criminal justice system.

Amicus Curiae's statement can be given in the written form (the document is referred to as Amicus Brief) or it can also be delivered orally in court. However, in practice so far, many have been given in the written form (Amicus Brief). ${ }^{5}$ In 2009, there were five nongovernmental organizations filed Amicus Curiae in the case of Prita Mulyasari who was alleged for criminal defamation against Omni International Hospital. These include The Indonesian Legal Aid and Human Rights Association (PBHI), the Indonesian Legal Aid Foundation (YLBHI), The Institute for Studies and Community Advocacy (ELSAM), The Institute for Criminal Justice Reform (ICJR) and The Indonesia Media Defense Litigation Network (IMDLN). ${ }^{6}$

Another Amicus Curiae's statement was submitted in 2017 in a blasphemy cases involving Basuki Tjahaja Purnama (Ahok). ${ }^{7}$ In this case, the role of Amicus Curiae was played by the Jakarta City Caring Woman (PPKJ) and the Jakarta Legal Aid Institute (LBH). ${ }^{8}$ Amicus Curiae's statement in this case was also given in the form of a document. Another Amicus Curiae submission wis a case of religious another blasphemy case committed by Meliana also involved Amicus Curiae. Several institutions submitted Amicus Curiae document to the Constitutional Court. These include the Indonesian Justice Supervisory Society (MaPPI), the Institute for Criminal Justice Reform (ICJR), the Indonesian Women's Coalition (KPI), Indonesian Legal Aid Center (PBHI) and several non-governmental organizations. Community (NGO) in North Sumatra. ${ }^{9}$ In this case the Amicus Curiae's statement was again proposed in written form, not in oral

\footnotetext{
2 "Amicus Curiae",

https:/ / www.law.cornell.edu/wex/amicus_curiae\#: :text=Latin $\% 20$ for $\% 20 \% 22$ friend $\% 20$ of $\% 20$ the,influ encing $\% 20$ the $\% 20$ court's $\% 20$ decision

${ }^{3}$ Kochevar, S. (2013). Amici Curiae in Civil Law Jurisdictions. The Yale Law Journal, 122(6): 1.

4 Gao, H. S. (2006). Amicus Curiae in WTO Dispute Settlement: Theory and Practice. China Right Forum, No.1 Edition 2006, p. 51.

${ }^{5}$ Aminah, S. (2014). Becoming a Court Friend: A Guide to Preparing an Amicus Brief. Jakarta: ILRC-Hivos, p. 11. 6 Hertanto (ed). (2009). Kasus Prita: Lima LSM Ajukan "Amicus Curiae". Kompas.com. https://megapolitan.kompas.com/read/2009/10/14/16474375/Kasus.Prita:.Lima.LSM.Ajukan..quot.Amicu s.Curiae.quot. (downloaded on 29 October 2018 at 22.29 WIB).

7 LBH Jakarta, 2017, Amicus Curiae (Amicus Brief) on the Blasphemy case of Mr. Basuki Tjahaja Purnama alias Ahok. Jakarta: LBH Jakarta.

8 Rochmi, M.N. (2017). Amicus Curiae buat Ahok, apa maknanya. https://beritagar.id/artikel/berita/amicus-curiae-buat-ahok-apa-maknanya. (accessed on 29 October 2018, at $22.34 \mathrm{WIB})$.

${ }^{9}$ Bhagaskoro, A. (2018). Dukungan Hukum bagi Terpidana Penodaan Agama Meliana Terus Bertambah. VOAIndonesia.com. https://www.voaindonesia.com/a/dukung-hukum-bagi-terpidana-penodaan-agamameliana-terus-bertambah/4582316.html (accessed on October 29, 2018 at 22.45 WIB).
} 
form. The last example of the Amicus Curiae submission was related to the persecution of the KPK's most popular investigatos, Novel Baswedan. ${ }^{10}$

Until 2019, there have been at least 24 cases submitting Amicus Curiae. Some judges considered Amicus Curiae in making their decisions, including a judge at the Muaro District Court, Sijunjung, West Sumatra in 2012. Amicus Curae was used intentionally in handling criminal cases and without the right to disseminate information aimed at creating hatred or enmity towards individuals and/or certain community groups based on ethnicity, religion, race, and intergroup (SARA) as stipulated in Article 28 paragraph (2) Law Number 11 of 2008 concerning Electronic Information and Transactions with the accused named Alexander An Pgl Aan. The judge, in his deliberation, stated "Given, ${ }^{11}$ From the judge's consideration, Amicus Curiae's statement is as documentary evidence.

Although there have been many practices of applying Amicus Curiae in Indonesia in recent years, however, there is no clear rule on it. As such, it is interesting to know the legal position of Amicus Curiae's in proving a crime and whether the document written by Amicus Curiae can be used as documentary evidence as intended in the Code of Criminal Procedure.

\section{Method}

This normative legal research uses studies legal principles and norms relating to the application of Amicus Curiae from various sources including laws, regulations, court decisions and doctrines.

\section{Analysis and Results}

3.1. Amicus Curiae as documentary evidence according to the Code of Criminal Procedure

Amicus Curiae basically is not a new, because the term of Amicus Curiae has existed since ancient Roman times. ${ }^{12}$ Over time, Amicus Curiae's existence has become increasingly recognized in the court, especially in criminal cases in Indonesia. Recently, Amicus Curiae has been practiced everywhere. There are even countries that pay special attention to the Amicus Curiae, such as England and Canada. ${ }^{13}$ Currently, there are no specific rules governing the participation of Amicus Curiae in the court, especially criminal cases in Indonesia, even though Amicus Curiae has submitted it to various courts in Indonesia for about 24 (twenty four) times. As a result of the absence of clear rules regarding the Amicus Curiae itself, especially regarding how this Amicus Curiae is included in the case currently being examined by the court to give its opinion, it has an impact on the ability to make every effort by Amicus Curiae to present his opinion before the court. As long as the efforts or methods made by Amicus Curiae to give his

10 Ramadhan, A., (2020). Kontras Serahkan Amicus Curiae Kasus Penyiraman Air Keras Novel Baswedan. Galih, B.(ed). https://nasional.kompas.com/read/2020/06/19/14290231/kontras-serahkanamicus-curiae-kasus-penyiraman-air-keras-novel-baswedan (accessed on July 21, 2020 at. 15.00 WIB). 11 Muaro District Court Decision Number: 45 / PID.B / 2012 / PN.MR

12 Mohan, S, C. (2010). The Amicus Curiae: Friends No More?. Singapore Journal of Legal Studies, 20(2):364.

13 Kochevar, S. (2013). Amici Curiae in Civil Law Jurisdictions. The Yale Law Journal, 122(6): 1653. 
opinion to the court on the case being examined do not conflict with the applicable criminal procedural law, this can be done.

Some of the Amicus Curiae practices that have occurred in Indonesia in recent years, the inclusion of Amicus Curiae to give his opinion on a case that is being examined by the court is through the defendant's attorney. However, even so, it does not mean that Amicus Curiae is involved in providing his opinion through other means. Amicus Curiae can also provide his opinion on cases that are currently being examined by the court through the Public Prosecutor. In addition, the opinion given by Amicus Curiae can also be directly given to the Chief Justice of the Constitutional Court and the Case Examining Council. Amicus Curiae or court friend, ${ }^{14}$ However, in practice, most of the Amicus Curiae gave their opinions in writing or document.

When Amicus Curiae gave his opinion at trial, there are basically no rules governing this. However, Nuryanto as the Judge at the Yogyakarta District Court stated that in giving his opinion at the trial, Nuryanto could have examined the evidence that relieved the defendant and it could also be during Pledoi depending on the form of opinion given by Amicus Curiae. If Amicus Curiae gives his opinion orally, then Amicus Curiae's opinion can be conveyed by examining the evidence. However, when Amicus Curiae gave his opinion in writing (document), the document made by Amicus Curiae was delivered in the Pledoi process through the defendant's attorney.

Regarding the application of the written by Amicus Curiae as evidence for criminal case document which are currently being examined in court, it is still a problem. The problem is, there are no rules in the Criminal Procedure Code in Indonesia that concretely regulates the enforcement of a document prepared by Amicus Curiae as a documentary evidence.

Due to the absence of law governing the enforcement of the document written by Amicus Curiae, which is widely practiced in Indonesia, has given its opinion in the form of a document in recent years, it has not been to convince the judge to use it as evidence. Indonesia itself, in its legal, there have been approximately 24 (twenty four) criminal cases filed by Amicus Curiae as a document evidence. From the 24 (twenty four) criminal cases filed by Amicus Curiae, there were 3 (three) criminal cases in which the Panel of Judges made Amicus Curiae as evidence in their consideration. From the 3 (three) cases in which the Panel of Judges used Amicus Curiae as evidence, 1 (one) case the Panel of Judges used as evidence for expert testimony, ${ }^{15}$ and 2 (two) cases in which the Panel of Judges decided as a document evidence in their consideration. Then there were 21 (twenty) cases, the document made by Amicus Curiae was not considered at all by the Panel of Judges.

2 (two) criminal cases in which the Panel of Judges enforced the document made by Amicus Curiae in the consideration of the decision as documentary evidence were the criminal case at the Muaro Sijunjung District Court with the case Number: 45 / Pid.B / 2012 / PN.MR on behalf of the defendant Alexander An . (Article 28 paragraph (2) 45 of Law subsection No. 11 of 2008) which at that time became Amicus Curiae was the Asian Human Rights Commission (Hong Kong) and the Case for Embezzlement at the Denpasar District Court Number: 780 / PID.B / 2014 / PN . DPS on behalf of Defendant March Vini Handoko Putra.

${ }^{14}$ Ma'ruf, N, J. (2018). Amicus Curiae's Position in the Resolution of Defamation in the Court (Case Study of Decision Number 1269 / Pid.B / 2009 / PN.Tng). (Thesis, Faculty of Law UII), Thesis, Islamic University of Indonesia. P. 25

15 The Panel of Judges that used Amicus Curiae's opinion as evidence of expert testimony was the decision of the Central Jakarta District Court with case No.344 / Pid.B / 2016 / PN.JKT.Pst. 
The existence of evidence has a very important and crucial role in the process of proving a criminal act, of course, it cannot be determined as it is. ${ }^{16}$ Likewise, documentary evidence which is one of the evidences as referred to in Article 184 paragraph (1) of the Criminal Procedure Code, cannot just be regulated. Not all document can be used as documentary evidence to prove someone is guilty or not guilty. However, one thing that must be known is that a written statement or "document" can only be used as documentary evidence by law must refer existing provisions. In the Criminal Procedure Code in Indonesia, the provisions governing documentary evidence in proving criminal cases can only be found in Article 187 of the Criminal Procedure Code. ${ }^{17}$

The document as referred to Article 187 KUHAP are as follows:

a. The minutes and other documents which prepared by authorized public officials or before them, which contain information about events or conditions that have been heard, seen or experienced, accompanied by clear and emphatic reasons for the statement.

b. The documents made based on the laws and regulation or by the functionary regarding to the responsible governance to prove something or some conditions.

c. A legal opinion from an expert.

d. Another document that may be valid if it has connection with the contents of other evidence only.

Based on the explanation of article $187 \mathrm{KUHAP}$, the founders of KUHAP only provide an explanation of the provisions set out in letter b. According to Sudikno Mertokusumo, there is unclear explanation of statutory regulations, then there is a method of interpretation ${ }^{18}$, Sudikno Mertokusumo's opinion was also supported by Mechteld Boot, Van Bemmelen and Van Hattum. According to Machteld Boot at Eddy OS Hiariej, every legal norm requires interpretation. In line with Machteld Boot are Van Bemmelen and Van Hattum at Eddy OS Hiariej said that any written regulation requires interpretation. ${ }^{19}$ Considering that the KUHAP is also a written regulation that contains legal norms, if the KUHAP does not provide a complete explanation, the KUHAP also can be interpreted. So even though Article 187 letter a, c, and d of the Criminal Procedure Code by the creators of the Criminal Procedure Code do not provide an explanation or consider its clear, but when law enforcers find something unclear, then the provisions in the article still need further interpretation.

Regarding the document written by Amicus Curiae, basically the Criminal Procedure Code itself does not provide concrete provisions regarding its enforcement as documentary evidence. However, whether or not the document written by Amicus Curiae can be used as documentary evidence, it is necessary to review Article 187 of the Criminal Procedure Code which regulates which document can be used as documentary evidence by judges. Basically, the Criminal Procedure Code itself only provides an explanation of Article 187 document $b$ of the Criminal Procedure Code, while Article 187 document a, c, and d of the Criminal Procedure Code does not provide any explanation at all. In this case, because KUHAP does not provide a

\footnotetext{
${ }^{16}$ Harahap, M, Y. (2016).Discussion on Problems and Application of KUHAP (Court Session Examination, Appeal, Cassation, and Review). Jakarta: Sinar Grafika, p. 273.

17 Hamzah, A. (2016). Indonesian Criminal Procedure Code. Jakarta: Sinar Grafika, p. 275.

18 Mertokusumo, S. (2014).Invention of the Law An Introduction. Revised Edition, Yogyakarta: Cahaya Atma Pustaka, p. 73.

${ }^{19}$ Hiariej, E, O. (2009). Legality Principles E Legal Discovery in Criminal Law. Jakarta: Erlangga, p. 65.
} 
complete explanation of the provisions of Article 187 of the Criminal Procedure Code in full, ${ }^{20}$ Therefore, to find out whether the document written by Amicus Curiae can be used as documentary evidence as referred to Article 187 of the Criminal Procedure Code, an interpretation method must be carried out by reviewing the document referred to in Article 187 of the Criminal Procedure Code. .

According to Hari Sasangka, the document as referred to Article 187 document a, b, and $c$ of the Criminal Procedure Code are document in official form..$^{21}$ This means that the document which is made by an authorized official, made based on the provisions of laws and regulations, made by the expert and the document is used to prove an incident from the beginning. Meanwhile, the document written by Amicus Curiae itself is basically an ordinary document. Document made by Amicus Curiae was not either made by authorized functionary nor based on statutory regulations. Referring to Article 187 letters a, b, and c of the Criminal Procedure Code, after the author of the analysis.

Furthermore, the document as referred to Article 187 document $\mathrm{d}$ of the Criminal Procedure Code explains that a document which can be used as documentary evidence is "another document which can only be valid if there is a connection with the contents of other evidence". According to Hari Sasangka, the document referred to in Article 187 document $\mathrm{d}$ of the Criminal Procedure Code is an ordinary document., it means that the document is not a document made by an authorized official, and is not made based on statutory regulations. Thus, Article 187 document $d$ of the Criminal Procedure Code provides an opportunity for document written by Amicus Curiae to be used as documentary evidence as mentioned in Article 187 document d KUHAP.

Document that can be used as documentary evidence as referred to in Article 187 document $\mathrm{d}$ of the Criminal Procedure Code do not pay attention to document from a formal perspective. However, the document in terms of material. If the document B is written by Amicus Curiae, the content/substance is in accordance with the facts that occur and it is related to the testimony of witnesses and expert testimony, the judge will make the document written by Amicus Curiae as evidence of the document in his consideration under Article 187 document d of the Criminal Procedure Code. So, the document written by Amicus Curiae does not have a standard form in the criminal case evidence system in Indonesia, but using the method of interpretation of Article 187 letter $a, b, c$,

In addition, the meaning of Article 187 document $\mathrm{d}$ of the Criminal Procedure Code is a document that must be depend on other evidence, according to M. Yahya Harahap, the document cannot be categorized as an evidence. Because if the part of evidence still has to be hung on other evidence, then the other document has no value for that evidence. Therefore, its refer as guiding evidence. ${ }^{22}$ Based on Article 188 paragraph (1) of the Criminal Procedure Code, meaning of indication is "an act, event or situation, which due to its suitability, both between one another and with the criminal act itself, shows that the perpetrator of the criminal act has occurred and who the perpetrator is." As evidence, the indication does not stand alone, means that the indication is obtained anther evidence, such as witness statements, document and statements from the

\footnotetext{
${ }^{20}$ Mertokusumo, S. Op. Cit, p. 73.

${ }^{21}$ Sasangka, H. \& Rosita, L. (2003). Law of Evidence In Criminal Cases. Bandung: Bandar Maju, p. 64.

22 Harahap, M, Y. Op. Cit, p. 309.
} 
defendant. Referring to the above, the information provided by Amicus Curiae in the form of a document is more likely to be used as evidence. Because the document written by Amicus Curiae can only be valid if there is relevance to the contents of other evidence and the document written by Amicus Curiae is not a document that can stand alone. As Eddy OS Hiariej also said, in the event that the document do not meet the requirements to be declared as documentary evidence, then the document can be used as evidence of guidance. However, whether or not a document can be used as evidence of guidance, all is depend to the judge's consideration..$^{23}$

\subsection{The Position of Amicus Curiae based on Criminal Procedure Law}

Judges in determining the guilty or not committing a criminal act, must refer to the negative evidence theory (negatief wettelijke bewijstheorie), which is in determining a person's guilty of committing a criminal act, the judge needs two valid evidences equipped with elements of the judge's conviction that the person is guilty of committing a crime criminal act. ${ }^{24}$ Therefore, to determine whether someone is guilty or not, the judge needs valid evidence. Article 184 paragraph (1) of the Criminal Procedure Code has stipulated limited means of evidence according to law, including witness statements, expert statements, document, orders, and statements of defendants. Apart from the evidence stated in Article 184 paragraph (1) of the Criminal Procedure Code, it cannot be used to prove the guilt of the accused. ${ }^{25}$ To be able to prove the guilt or innocence of a defendant who is being charged by the public prosecutor, the strength of the evidence strongly supports the judge's decision in deciding cases in court. ${ }^{26}$

According to Eddy OS Hiariej, basically the power of evidence of each evidence in assessing the evidence of indictment is the judge's authority. The judge has the authority to evaluate and determine the suitability of one piece of evidence. The strength of the evidence itself lies in the evidence presented, whether the evidence presented is relevant or not with the case being tried. In criminal procedural law, basically the strength of all evidence is same. It means that no one piece of evidence exceeds the other, because evidence in a criminal case does not recognize the hierarchy. However, there are provisions that require a link between one piece of evidence and another. ${ }^{27}$

Document evidence is one of several valid evidences in a criminal case. Document that can be used as evidence are document as referred to in Article 187 KUHAP. Regarding the document written by Amicus Curiae, as previously discussed by the author, it can be used as documentary evidence based on Article 187 document $\mathrm{d}$ of the Criminal Procedure Code, as long as the document written by Amicus Curiae has links with other evidence both as witness testimony, expert testimony as well as testimony from the defendant, so that the document prepared by Amicus Curiae can be used as documentary evidence. However,

According to M. Yahya Harahap, assessing the legal position of evidence attached to documentary evidence can be seen from a theoretical perspective and relates it to several evidentiary principles set out in the Criminal Procedure Code. ${ }^{28}$ Therefore, to

\footnotetext{
${ }^{23}$ Hiariej, E, O. (2012). Theory and Law of Evidence. Jakarta: Erlangga, p. 109.

24 Hamzah, A. Op. Cit, p. 255

${ }^{25}$ Harahap, M, Y. Op. Cit, p. 285

26 Rusyadi. (2016). Strength of Evidence in Criminal Court proceedings. Journal of Law Prjoris, 5 (2): 130

27 Ibid,

${ }^{28}$ Harahap, M, Y. Op. Cit, p. 309
} 
determine the legal position of the document written by Amicus Curiae, it must also be seen from a theoretical point of view and be linked to the principle of evidence regulated in the Criminal Procedure Code.

\subsubsection{Formal Perspective}

Formally, documentary evidence as referred to Article 187 document $a, b$, and c of the Criminal Procedure Code is "admissible" evidence. This is because the document forms as referred to in Article 187 document a, b, and c of the Criminal Procedure Code are made formally in accordance with the formalities stipulated in the statutory regulations. With the fulfillment of the formal provisions in the making and containing official information from the competent official and the preparation and information contained and made with an oath of office, then in terms of formal documentary evidence as referred to Article 187 document $a, b$, and c of the Criminal Procedure Code constitute evidence that has a admissible value. ${ }^{29}$

If the document referred to Article 187 document $a, b$, and c of the Criminal Procedure Code are seen from a formal perspective, constitute admissible evidence, this is different from the document referred to Article 187 document $\mathrm{d}$ of the Criminal Procedure Code. The document referred to in the article is only valid as documentary evidence, if the document has connection with other evidence such as witness testimony, expert testimony, and statement of the defendant. If the document has no relevance to other evidence, then the document cannot be used as documentary evidence. The above also applies to document written by Amicus Curiae. The document written by Amicus Curiae can be used as evidence based om Article 187 document d of the Criminal Procedure Code. Finally, if it seen from a formal perspective is not the evidence.

\subsubsection{Material Perspective}

Materially, all forms of documentary evidence as referred to Article 187 of the Criminal Procedure Code, are not evidence that has binding legal force. Documentary evidence does not attach binding legal force as evidence. The value of the legal position of documentary evidence is basically the same as the legal position of witness testimony and expert testimony. Namely, both have legal force as independent evidence. ${ }^{30}$ This means that the judge has the freedom to judge rather than the strength of the evidence. Viewed from this material, the power of document law does not see the perfection of the evidence from a formal perspective. Although the document evidence referred to in Article 187 document a, b, and c of the Criminal Procedure Code are admissible evidence from a formal perspective, this does not mean that the document mentioned in the article themselves have binding legal force. ${ }^{31}$ The document written by Amicus Curiae basically, is not legally binding. Judges are free examine the document written by Amicus Curiae. There is no obligation for the judge to accept the truth of the document written by Amicus Curiae.

Based on the explanation of the legal position of document evidence, both from a formal and material perspective, it can be seen that the document written by Amicus Curiae from a formal perspective is not a documentary evidence that has legal force as

${ }^{29}$ Ibid, p. 310

30Ibid, p. 310

31 Ibid, 
an admissible evidence. Meanwhile, in terms of material, the document written by Amicus Curiae is basically not documentary evidence that is not legally binding. This means that the judge has the freedom to use the document for his consideration. Judges are not obliged to be bound by a document written by Amicus Curiae.

The main point in assessing the legal position of the document written by Amicus Curiae as documentary evidence in proving a criminal case is on Amicus Curiae has links/links with other evidence and also the extent to which the contents/substance of the document Amicus Curiae to convince the judge. Therefore, basically, the document written by Amicus Curiae has free and non legal binding force. The legality of the document written by Amicus Curiae really depends on judge's consideration. The judge can judge based on his conscience whether the document written by Amicus Curiae is strong enough or not to be used as a basis for judge's consideration in deciding a case. ${ }^{32}$

\section{Conclusion}

The legal position of the document written by Amicus Curiae remains unclear. There is no regulation that explicitly addresses the legal position of document written by Amicus Curiae. Therefore, it is not easy to place it within the Indonesian law of evidene, whether considered as witness testimony, expert testimony, documentary evidence, or circumstantial evidence. In fact, there have been three criminal cases employing Amicus Curiae as evidence, either as expert testimony or documentary evidence. The formed was shown by a judge at the Central Jakarta District Court while the latter was shown by the panel of judges at Muaro Sijunjung District Court, West Sumatra and Denpasar District Court. There two points of view regarding the legal enforcement of the document written by Amicus Curiae, formal and material point of view. From the formal point of view, the document written by Amicus Curiae is an admissible evidence that has an evidential value only if it is related to other forms of evidence. From the material point of view, the judges have freedom to assess the evidential value of the document written by Amicus Curiae.

\section{References}

Books:

Dewata, M, F, N \& Achmad, Y. (2010). Dualism of Normative \& Empirical Legal Research. Yogyakarta: Student Library.

Hamzah, A. (2016). Indonesian Criminal Procedure Code. Jakarta: Sinar Grafika.

Harahap, M, Y. (2016). Discussion on Problems and Implementation of KUHAP (Court Session Examination, Cassation, and Review). Jakarta: Sinar Grafika.

Hiariej, E, O. (2012). Principles of Legality \& Legal Discovery in Criminal Law. Jakarta, Erlangga.

Hiariej, E, O. (2012). Theory and Law of Evidence. Jakarta: Erlangga

Mertokusumo, S. (2014). Legal Discovery An Introduction, Revised Edition. Yogyakarta: Cahaya Atma Pustaka.

32 Rishad, A. (2018). The Role of Amicus Curiae for Judges in Deciding in the Criminal Justice System in Indonesia. Thesis, Gadjah Mada University 
Muhammad, R. (2007). Contemporary Criminal Procedure Law. Bandung :PT Citra Aditya Bakti.

Sasangka, H. \& Rosita, L. (2003). Law of Evidence In Criminal Cases. Bandung: Bandar Maju.

\section{Journal Articles:}

Gao, H. S. (2006). Amicus Curiae in WTO Dispute Settlement: Theory and Practice. China Right Forum, No.1 Edition 2006: 51-57.

Kochevar, S. (2013). Amici Curiae in Civil Law Jurisdictions. The Yale Law Journal, 122(6): 1653-1669.

Mohan, S, C. (2010) The Amicus Curiae: Friends No More?. Singapore Journal of Legal Studies, 20(2): 352-374.

Rusyadi. (2016). Strength of Evidence in Criminal Court proceedings. Journal of Law Prjoris, 5 (2): 128-134.

\section{Documents:}

Adnan, A. W. (2016). The Negative Application of Evidence Theory according to the Law (negatiefWettelijke Stelsel in the Murder Criminal Court Session (Case Study of Court Decision No.1361 / Pid.B / 2005 / PN.Jkt.Pst). Thesis, Gadjah Mada University.

Aminah, S. (2014). Becoming a Court Friend: A Guide to Compiling an Amicus Brief. Jakarta: ILRC-Hivos.

LBH Jakarta. (2017). Amicus Curiae (Amicus Brief) on the Blasphemy case of Mr. Basuki Tjahaja Purnama alias Ahok. Jakarta: LBH Jakarta.

Ma'ruf, N, J. (2018). Amicus Curiae's Position in the Resolution of Defamation in the Court (Case Study of Decision Number 1269 / Pid.B / 2009 / PN.Tng), (Thesis, Faculty of Law, UII). Thesis, Islamic University of Indonesia.

Rishad, A. (2018). The Role of Amicus Curiae for Judges in Deciding in the Criminal Justice System in Indonesia. Thesis, Gadjah Mada University.

Wicaksana, D, A. Dkk. (2018). Written Comments as Amicus Curiae (Court Friend) Regarding Case Number 1612 / Pid.B / 2018 / PN.Mdn in Medan District Court, Material for Consideration for the Panel of Judges. Jakarta: Indonesian Judicial Monitoring Society.

\section{Regulations:}

Denpasar District Court Decision Number: 780 / Pid.B / 2014 / PN.DPS.

Law Number 39 of 1999 concerning Human Rights (State Gazette of the Republic of Indonesia of 1999 Number 165, Supplement to the State Gazette of the Republic of Indonesia Number 3886). 
Law Number 48 of 2009 concerning Judicial Power (State Gazette of the Republic of Indonesia of 2009 Number 157, Supplement to the State Gazette of the Republic of Indonesia Number 5076).

Law Number 8 of 1981 concerning Criminal Procedure Law (State Gazette of the Republic of Indonesia of 1981 Number 76, Supplement to the State Gazette of the Republic of Indonesia Number 3285).

Muaro District Court Decision Number: 45 / PID.B / 2012 / PN.MR.

\section{Internet:}

Ramadhan, A., (2020). Kontras Serahkan Amicus Curiae Kasus Penyiraman Air Keras Novel Baswedan. Galih, B.(ed).

https://nasional.kompas.com/read/2020/06/19/14290231/kontras-serahkanamicus-curiae-kasus-penyiraman-air-keras-novel-baswedan (accessed on July 21, 2020 at. $15.00 \mathrm{WIB})$.

Hertanto (ed). (2009). Kasus Prita: Lima LSM Ajukan "Amicus Curiae". Kompas.com. https://megapolitan.kompas.com/read/2009/10/14/16474375/Kasus.Prita:.Li ma.LSM.Ajukan..quot.Amicus.Curiae.quot. (downloaded on 29 October 2018 at 22.29 WIB).

Rochmi, M.N. (2017). Amicus Curiae buat Ahok, apa maknanya. https://beritagar.id/artikel/berita/amicus-curiae-buat-ahok-apa-maknanya. (accessed on 29 October 2018, at 22.34 WIB).

Bhagaskoro, A. (2018). Dukungan Hukum bagi Terpidana Penodaan Agama Meliana Terus Bertambah. VOAIndonesia.com. https://www.voaindonesia.com/a/dukunghukum-bagi-terpidana-penodaan-agama-meliana-terusbertambah/4582316.html (accessed on October 29, 2018 at 22.45 WIB). 